\author{
M. F. Shatskaya, \\ Candidate of Philology, \\ Associate Professor of the Russian language and methods of teaching it \\ Volgograd State Pedagogical University, \\ 27, Lenin avenue, Volgograd, 400066, Russia, \\ tel.: (8442) 302825, \\ marina.schatzckaya@yandex.ru
}

\title{
SEMANTIC DYNAMICS OF THE QUANTIFIER 'ZERO' IN THE RUSSIAN LANGUAGE
}

\section{Summary}

The article deals with the semantic dynamics of one of the quantifiable indicators - the lexeme 'zero'. This quantitative indicator came into the life of society and the language system much later than other similar words. 'Zero' appeared specifically, on the periphery of the spheres of human activity, gradually taking an increasingly important place first in the pre-scientific, and then in a truly scientific understanding of reality. In Russian, the value of zero has long been transmitted by the word digit. According to etymological dictionaries, the quantitative meaning of the noun 'zero' was first noted only in Peter the Great's era. In modern Russian language the lexeme 'zero' functions in several senses, all of which in most lexicographical sources mean 'real number'.

In the course of the development of the Russian language zero has undergone many semantic transformations: from the actual quantitative indicator of meaning to the formation in a certain sense of something paradoxical and anomalous. Thus, zero contains gradation, parametricity, as well as anthropomorphic, physiological and abstract characteristics. In addition, the potential of this token has not yet been exhausted. The lexeme 'zero' continues its semantic development: in journalistic, poetic, colloquial speech there are cases of semantic derivation due to the increment of semes / seme complexes to already known meanings, syntactic variation of idioms, development of metaphor, interaction with the words of other thematic, lexical and semantic groups. The semantic dynamics of the lexeme 'zero' was characterized by simultaneous multidirectional, sometimes diametrically opposite processes under the influence of both external and internal factors of linguistic and socio-cultural genesis.

Key words: token, zero, quantifier, semantic dynamics, idiom.

Надійшла до редакиії 30.08.2019 p.

УДК $811.163 .41 ’ 366: 811: 16$

DOI: https://doi.org/10.18524/2413-0613.2019.23.183125

\section{B. І. Ярмак,}

доктор філологічних наук, доцент,

старший науковий співробітник відділу слов'янських мов

Інституту мовознавства ім. О. О. Потебні НАН України,

01001, Україна, м. Київ, вул. М. Грушевського, 4,

тел.: (044) 279-02-92; inmo2006@ukr.net,

veronikaarmak1@gmail.com

\section{ПЕРЕКЛАДАЦЬКІ РІШЕННЯ В ІНТЕРПРЕТАЦЇ̈ СЕРБСЬКОГО ХУДОЖНЬОГО ДИСКУРСУ БІЛОРУСЬКОЮ МОВОЮ}

У статті проаналізовано широкий спектр перекладацьких трансформацій у зразках інтерпретацій сербського художнього дискурсу білоруською мовою. Особливу увагу приділено перекладацьким експериментам, стосовним особливостей відтворення сербських дієслівних форм минулого часу в мові перекладу. Домінантне становище серед численних варіантів перекладацьких рішень у цьому контексті посідає морфологічна заміна, що зумовлено значними відмінностями в конфігурації претеритальних систем сучасних сербської та білоруської мов. Сучасна білоруська 
універсальна дієслівна форма минулого часу здатна відбивати відтінки не лише сербського перфекта iз допоміжним дієсловом, а й усіченого перфекта, синтетичного аориста тощо. Розглядаються найпоширеніші перекладацькі труднощі в перекладі „простих”, традиційних і нібито стилістично нейтральних форм сербського дієслова, здатних, проте, концентрувати глибокі смисли. Чільне місце посідає дослідження можливих контекстуальних білоруських еквівалентів сербського перфекта без допоміжного дієслова, а також шляхів передання білоруською мовою неоднозначних за своєю семантикою претеритальних форм сербського дієслова.

Ключові слова: художній переклад, перекладацькі трансформації, морфологічна заміна, претеритальні форми сербського дієслова, білоруські дієслівні форми минулого часу.

Як не парадоксально, на початку XXI ст. міжслов'янський художній переклад залишається малодослідженою галуззю українського мовознавства. Прикрою лакуною на згаданій ділянці є, зокрема, проблематика інтерпретації сербських дієслівних форм минулого часу білоруською мовою, яка, на відміну від південнослов’янської (сербської), належить до східнослов’янського мовного ареалу. Проте актуальність цієї теми зумовлюється не лише недостатнім вивченням спектру можливих практичних перекладацьких рішень, а й широкими можливостями осмислення теоретичних проблем динаміки історичного розвитку претеритальних систем сербської та білоруської мов, що

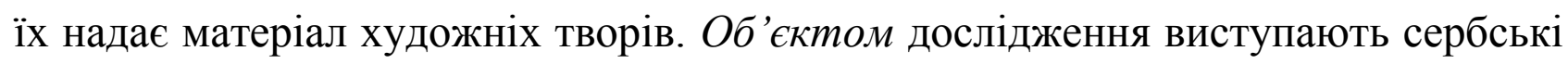
та білоруські претеритальні форми дієслова, а предметом - види перекладацьких трансформацій в інтерпретації сербського художнього дискурсу білоруською мовою. Метою дослідження є визначення особливостей перекладацьких рішень при передачі сербських дієслівних форм минулого часу в білоруській мові в контексті особливостей історичного розвитку цих мов. Методи дослідження визначаються специфікою художнього матеріалу: це, зокрема, метод лінгвістичного спостереження й опису, метод філологічного контекстологічного аналізу, порівняльний метод, а також методи семантичного і структурного аналізу.

Багату гаму перекладацьких трансформацій, серед яких переважає заміна сербських морфологічних форм минулого часу, знаходимо в перекладах сербського художнього дискурсу білоруською мовою, що пройшла тривалий шлях історичного розвитку, внаслідок чого в ній викристалізувалася конфігурація претеритальної системи, подібна до тієї, що склалася в 
українській і російській мовах. Логічно й стилістично вмотивовану заміну сербських форм перфекта притаманною сучасній білоруській мові універсальною формою минулого часу знаходимо в білоруському перекладі вірша Д. Максимович „Прошу помилування” зі збірки „Ліричні дискусії зі зведенням законів короля Душана”, виконаному письменником і перекладачем Н. Гілевичем. Відомо, що поетеса завжди була небайдужою до жіночої проблематики: закінчивши свого часу Белградський університет, вона згодом продовжила навчання у Сорбонні, де захистила дипломну роботу про Жанну Д’Арк, а пізніше, - іще до отримання визнання, численних престижних літературних премій і обрання до Сербської академії наук і мистецтв, викладала в жіночих гімназіях. У вільному вірші з римою, що зустрічається лише подекуди, монологи авторитарного середньовічного сербського царя Душана Сильного, спрямовані на утвердження сили закону, перехрещуються 3 монологами ліричної героїні, яка заступається за представників простого народу, жінок, слабких, сіромашних і стражденних, утверджує велич кохання й поезії. Зокрема, в одному з ліричних фрагментів авторка у проникливому й емоційному монолозі просить у царя Душана милосердя для бездітних жінок. Цю тональність, яка не в останню чергу грунтується й підтримується за рахунок уживання претеритальних форм дієслова, успішно передано і в перекладі: „Благоразумевање тражим за жене које нису дале богу божије ни цару царево, које нису занихале (тут і далі курсив наш - В. Я.) у колевци дете...” [4, с. 136]„Спагады разумнай прашу для жанчын, якія не далі ні богу богава, ні цару царова, якія не калыхалі дзіцяці ў калысцы...” [3, с. 275].

Той самий вид трансформації спостерігаємо і в перекладах тих пасажів, де Д. Максимович розширює коло людей, до яких вона вимагає гуманності: від бездітних жінок до знаменитих жінок, які присвятили своє життя поезії $\mathrm{i}$ благородному служінню людям, у тому числі й для себе особисто: „Тражим помиловање, драги царе, за оне које су од младости ране приволеле се царству поезије...” [4, с. 136] - „Добры цару, твайго злітавання прашу для тых, хто ў пару маладосці стаў падданым царства паэзіі...” [3, с. 276]. Поблажливого ставлення 
просить поетеса і для своєї рідної землі, також використовуючи при цьому форму перфекта: „За земљу, за слово љубве, поезију љубавну њену, ...за славуја, за њега, за свакога који је пао немилости - помиловања!” [4, с. 140]. Білоруським відповідником у перекладі знову виступає „універсальна” дієслівна форма минулого часу: „Для любае зямлі, для вершаў пра каханне, для спевака-дразда $\mathrm{i}$ салаўя, для ўсіх, для кожнага, як ты і я, хто трапіў у няміласць - памілавання!” [3, c. 276].

Звісно, як перекладач Н. Гілевич стикається з необхідністю відтворення i складніших дієслівних форм минулого часу, ніж сербський перфект. Наприклад, білоруська універсальна дієслівна форма минулого часу знов стає перекладачеві у пригоді в інтерпретації складного, епічного за своїм задумом твору „Оплакування Смедерева” Міодрага Павловича, знаного сербського письменника, поета, есеїста, академіка Сербської академії наук і мистецтв. У центрі поезії - драматичні історичні колізії, адже вірш присвячено подіям у місті Смедереві, яке в добу середньовіччя було столицею, адміністративним центром і найбільшим містом Сербії. У 1458 р. його було завойовано османами, а в 1459 р. перетворено на Санджак Смедерево. Невеликий за обсягом твір характеризується складністю часових нашарувань, розлогістю описів i різноманітністю використовуваних претеритальних форм дієслова. Зокрема, М. Павлович майстерно „маневрує” у плані використання аористів, перфектів $\mathrm{i}$ усічених перфектів: „Остадосмо без града и без закона, град је пао. ...Зидине с именима нашим падоше, река их однела.... Да певамо и да се сами себе сећамо, други су нас заборавили" [6, с. 71-72]. Відтворюючі цю поліфонію, Н. Гілевич передає всі відтінки (динамізм дії, особисту пережитість тощо) за допомогою форм минулого часу, утворених від дієслів доконаного виду: „Астаёмся без горада і без закона, горад знік. ... Сцены з імёнамі нашымі рухнулі, іх знесла рака.... Каб пець і саміх сябе ўспамінаць, іншыя нас забылі" [3, с. 284]. У гарному білоруському перекладі певні сумніви викликає лише перша дієслівна форма, адже тут інтерпретатор вирішив перенестися до площини теперішнього часу. Певно, що в цьому випадку це не має істотного значення і не впливає на 
загальний рівень перекладу, який не мусить бути дослівним, проте, на нашу думку, сербська форма форма „остадосмо” однозначно має у своєму спектрі семантику завершеності дії.

Показовим є й відтворення в білоруському перекладі особливостей часових параметрів вірша М. Павловича „Полювання”, який граматично повністю побудований на частому вживанні різних дієслівних форм минулого часу. Початок поезії грунтується, зокрема, на формах перфектів, ужитих для колоритного опису подій і відчуттів персонажів: „Брата сам повео у лов зором у гору, добре смо коње имали и стреле кремене, шума је пуна звериња била. Но брат je мој ћутљиви говор животиња разумевао: вуци су нам о братству говорили, медведи о правди, у вепру се чуо чукундеде глас...” [6, с. 11]. Білоруські еквіваленти цих дієслівних форм постають перед нами в перекладі Н. Гілевича: „Паляванне Брата павёў я на паляванне дасвеццем у лес, добрыя коні былі ў нас і крамянёвыя стрэлы, дзічыны было ў лесе поўна. Але маўклівы мой брат мову жывёл разумеў: ваўкі гаварылі пра брацтва, мядзведзі - пра справядлівасць, у вепра пачуўся прапрадзедаў голас...” [3, с. 284-285]. У другій строфі часовий фон набуває в поезіі М. Павловича поліфонічного звучання завдяки розширенню спектра формальних засобів репрезентації плану минулого і за рахунок уживання цілої низки експресивних форм аориста: „, ...у птицама се огласише сестре неке, сиротице неудате ил нерођене, те много дана дуже ловисмо све праву да сретнемо звер" [6, с. 284]. Перекладач передає цю динамічність, послуговуючись універсальними дієслівними формами минулого часу білоруської мови: , ...птушкамі азываліся сёстры, удовы, сіроты i ненароджаныя... Шмат дзён спадзяваліся мы, што стрэнем сапраўднага звера” [3, с. 284-285]. У кінці вірша, описуючи драматичні події, пов'язані 3 поверненням братів із полювання, М. Павлович дещо сповільнює темп, знову вдаючись до гнучких перфектів із допоміжними дієсловами й усіченого перфекта, синтетична ж форма аориста виступає тут лише як вкраплення: „Тако смо се и вратили у село руку празних и гладни. Ругали нам се кметови, љубе нас неверне напустиле и благо собом понеле, ни у манастир нас просјаке не примиме да се под кров склонимо и прехранимо. 
Једино коњи $c y$ нас верно носили из мање у већу даљину и птице нам летеле над главама...” [5, с. 30]. Н. Гілевич переконливо демонструє, що білоруська форма минулого часу здатна передати всі відтінки значення. Як видно з білоруського відповідника цього фрагмента, контекстуальним еквівалентом усіченого перфекта може виступати дієприслівник минулого часу („понеле” - „забраўшы”): „Ды так і вярнуліся ў вёску галодныя і з пустымі рукамі. Стараста лаяў нас моцна, любыя здрадзілі нам і пакінулі, забраўшы з сабой пажытак, і старцы ў манастыр не nycuілi, каб даць нам яду і прытулак. Толькі коні нас верна насілі з меншай даліны ў большую, ды птушкі лёталі ў нас над галовамі...” [3, с. 285].

Цікавими видаються особливості відтворення в білоруському перекладі й неоднозначних за своєю семантикою сербських дієслівних форм минулого часу 3 класичних віршів визначного сербського поета XX століття, академіка В. Попи, із їхньою загальною характерною схильністю до лапідарності, стислості, еліптичності висловлювання. Помітний відбиток на поетовій манері залишив той факт, що під час Другої світової війни він був в'язнем фашистського концентраційного табору. Багато драматичних (зорових i слухових) вражень від цього періоду згодом втілилися у його емоційно напружених віршах-настроях, із розпливчастими обрисами хронотопів, без рими й розділових знаків, зокрема у поезії „Відлуння”: „Prazna soba stane da reži Uvučem se u svoju kožu Tavanica stane da skiči Hitnem joj jednu kost Uglovi stanu da kevču ... Pod stane da zavija ... Jedan zid stane da laje ... I drugi i treći i četvrti zid Stane da laje..." [12]. Семантика ужитих поетом розширених дієслівних форм із часткою „да” тяжіє до претеритальної, увібравши при цьому відтінок ітеративності, проте, незважаючи на численні повтори цієї моделі, вона не втрачає відчутного зв'язку з теперішнім часом. Перекладач Н. Гілевич добре впорався зі своїм завданням, обравши для інтерпретації, вочевидь, єдино можливу адекватну дієслівну форму: „Стане пакой рыпаџь Уцягваюся ў сваю скуру Столь скуголіщь пачне Кіну адну ёй костку Яхкаџь куты пачнуць... Стане падлога выцьь ... Стане сцяна брахаць...” [3, с. 278]. У ліричному вірші „Звідки мої очі...”, навіть без використання претеритальних форм дієслова, В. Попа у 
метафорично-філософській формі висловлює власне ставлення до часу, характерне для поетичного сприйняття світу, ототожнюючи його, зокрема, 3 легкою гілкою. Таке ставлення дається взнаки і $є$ імпліцитно присутнім у багатьох його віршах: „U korice da vratim Boje zoru Na lakoj grani vremena” [11]. Це образне тлумачення Н. Гілевич майстерно відтворює в перекладі білоруською мовою: „Вярнуць у ножны Бітвы спеюць На лёгкай галіне часу” [3, с. 278]. Перфект із допоміжним дієсловом використовується і в повторі, яким починаються перша й остання строфи вірша „Слово - вогонь” Бранка Мільковича, поета-неореаліста другої половини XX ст. Дискурс поета, якого, за його власним висловленням, „спалили слова”, завжди надзвичайно експресивний: „Reč vatra! Ja sam joj rekao hvala što živim - toj reči čiju posedujem moć da je kažem" [9]. У перекладі Н. Гілевич, без жодної шкоди для семантики й емоційної виразності, вдається до опущення дієслівної форми, не перекладаючи iii буквально, і майстерно надолужує смисл: „Слова - агонь! Хвала, што Жывы 1 пішу, слову, што сілы дае мне, яго каб прамовіць” [3, с. 286].

Морфологічну заміну сербських претеритальних форм дієслова спостерігаємо в інтерпретації фрагментів із філософської збірки I. Андрича „Знаки вздовж дороги” в перекладі білоруською мовою Г. Наумової: „Toliko je bilo u životi stvari kojih smo se bojali. A nije trebalo. Trebalo je živeti” [10, c. 21] „У жыцці было многа рэчаў, які мы баяліся. А так нельга. Варта было жыць” [1, с. 224]. Перфект із допоміжним дієсловом є домінантною формою минулого часу дієслова у творах цього письменника, а свої змістовні висловлювання філософсько-есеїстичного характеру він зазвичай оформлює за допомогою „універсальних” форм перфекта, котрі в іншомовній інтерпретації потребують заміни білоруськими дієслівними формами минулого часу, до якої і вдається перекладач (щоправда, іноді цілком слушно заміняючи сербський претерит дієприкметником: „,su rekli” - „сказанае”): „Otišao sam. Iza mene je ostalo sve što $s u$ ljudi rekli, kao pramičak magle koji se gubi. A sve što su uradili, poneo sam na dlanu jedne ruke” [7.] - „Я адыишоў. Пасля меня засталося усё сказанае людзьмі, як тыя космы туману, што знікаюць. А ўсё, што яны зрабілі, я панёс на далоні 
адной руки" [1, с. 224]. Як і більшість справжніх письменників, свої думки I. Андрич висловлює за допомогою порівняно простих мовних засобів, здатних концентрувати в собі глибокі смисли: „Sve što nisam nikad mogao u snu naslutiti ni na javi videti, kazala mi je nesanica svojim nemim i mračnim govorom" [8] „Пра усё тоє, чаго я ніколі не мог ні адчуць у сне, ні ўбабащіџь наяве, нема і змрочна гаварыла мне бяссоніца” [1, с. 225].

Проаналізований мовний матеріал дає підстави стверджувати, що переклад претеритальних форм сербського дієслова засобами споріднених східнослов'янських мов віддзеркалює не лише закладений у сербських претеритальних формах семантико-експресивний заряд, а й потенційні виражальні можливості, які в українській і російській мовах було давно втрачено. Свого часу академік Л. А. Булаховський, автор вступної статті й пояснення до збірника „Сербська народна поезія” в перекладі українською мовою, справедливо зауважував, що „перекладач часто переборює труднощі, далеко більші, бо не має тієї свободи, якою користується автор, і примушений за самою природою свого завдання зважати на настанови автора - знаходити в мові, на яку він перекладає, засоби вираження, еквівалентні (рівноцінні) тим, які автор обрав із свосї рідної мови" [2, с. 301-302].

Отже, аналіз сербського й білоруського художнього матеріалу переконливо свідчить, що саме особливості динаміки історичного розвитку обох досліджуваних мов спричинили статус морфологічної заміни як домінантного різновиду перекладацьких трансформацій в інтерпретації сербського художнього дискурсу білоруською мовою. Сучасний міжслов'янський художній переклад $є$ ключем до відтворення внутрішньої форми й первісної семантики сербських дієслівних форм минулого часу, котрі білоруська мова давно втратила. Проте усе розмаїття відтінків сербських претеритальних форм минулого часу (зокрема й синтетичних) без будь-яких втрат для їхнього семантико-експресивного наповнення успішно відтворюється за допомогою білоруських „універсальних” дієслівних форм минулого часу. Результати дослідження стануть у пригоді передусім у викладанні спецкурсів, 
присвячених міжслов’янському художньому перекладу, історії та історичної граматики сербської i білоруської мов. Художній матеріал може використовуватися і в лексикографічній практиці: в укладанні перекладних двомовних словників - сербсько-білоруських і білорусько-сербських.

\section{Список використаних джерел та літератури}

1. Андрыч І. Знакі ўздоўж дарогі (перакл. Г. Навумавай) // Дзеяслоў. Літературна-мастаџькі часопис. Мінск, 2013. № 2 (63). С. 223-227.

2. Булаховський Л. А. Нариси з загального мовознавства. К.: ДУПВ „Рад. шк.”, 1959. 307 с.

3. Гілевіч Н. Роднасць: Выбр. пер. са слав. паэтаў. Мінск: „Мастацкая література”, 1983. 367 с. URL: http://pushlib.org.by/node/1079/

4. Максимовић Д. Тражим помиловање: лирске дискусије с Душановим закоником. I Am Seeking a Pardon: lyric discussions with Dušan's code; translated from the Serbian by Dragan Purešić. Београд: Народна библиотека Србије, 2013. 190 с.

5. Павловић М. Глас под. каменом. Pavlović V. Glas pod Kamenom. Transited by B. Callaghan (with an Afterword by R. Marteau). Toronto. Exile Editions, 1985. P. 30.

6. Павловић М. Оплакивање Смедерева // Антологија српске књижевности „Србија до краја века”, 2010. 373 c. URL:www.antologijasrpskeknjizevnosti.rs/ASK_SR_AzbucnikPisaca. aspx/

7. Andrićevi citati koji se pamte celog života, s. a. URL: https://www.pismenica.rs/knjizevnost/andricevi-citati-koji-se-pamte-celog-zivota/

8. Andrić I. Znakovi pored puta. Svjetlost: Sarajevo,Prosveta: Beograd, s. a. 335 s. URL: https://ru.scribd. com/doc/36814767/Andric-Ivo-Znakovi-pored-puta/

9.Miljković B. Reč vatra, 2017. URL: https://urakultura.wordpress.com/2017/08/19/rec-vatra-branko miljkovic

10. Misli znemenitih Srba. Priredila D. Antić. 3-će. izd. Beograd: Alnari, 2003 (Beograd: Plavo slovo). 173 s.

11. Popa V. Kalenić, s. a. URL: http://www.prelepapoezija.com/kalenic/

12.Popa V. Odjekivanje s. a. URL: http://www.prelepapoezija.com/odjekivanje/

\section{References}

1. Andrych I. Znaki uzdouzh darohi (perakl. H. Navmavay) // Dzeyaslou. Literaturna-mastats'ki chasopis. Minsk, 2013. No. 2 (63). P. 223-227.

2. Bulahovsky L. A. Narysy z zahal’noho movoznavstva. K.: DUPV „Rad. shk.”, 1959. 307 p.

3. Hilevich N. Ronasts’: Vybr. per. sa slav. paetau. Minsk: „Mastatskaya literature”, 367 p. URL: http://pushlib.org.by/node/1079/

4. Maksimović D. Tražim pomolovanje: lirske dikusije s Dušanovim zakonikom. I Am Seeking a Pardon: lyric discussions with Dušan's code; translated from the Serbian by Dragan Purešić. Beograd: Narodna biblioteka Srbije, 2013. 190 p.

5. Pavlović M. Glas pod kamenom. Pavlović V. Glas pod Kamenom. Translted by B. Callaghan (with an Afterword by R. Marteau). Toronto. Exile Editions, 1985. P. 30. 
6. Pavlović M. Oplakivanje Smedereva // Antologiya srpske književnosti "Srbija do kraja veka", 2010. 373 p. URL: www.antologijasrpskeknjizevnosti.rs/ASK_SR_AzbucnikPisaca. aspx/

7. Andrićevi citati koji se pamte celog života, s. a. URL: https://www.pismenica.rs/knjizevnost/andricevi-citati-koji-se-pamte-celog-zivota/

8. Andrić I. Znakovi pored puta. Svjetlost: Sarajevo,Prosveta: Beograd, s. a. 335 s. URL: https://ru.scribd. com/doc/36814767/Andric-Ivo-Znakovi-pored-puta/ miljkovic

9.Miljković B. Reč vatra, 2017. URL: https://urakultura.wordpress.com/2017/08/19/rec-vatra-branko

10. Misli znemenitih Srba. Priredila D. Antić. 3-će. izd. Beograd: Alnari, 2003 (Beograd: Plavo slovo). 173 s.

11. Popa V. Kalenić, s. a. URL: http://www.prelepapoezija.com/kalenic/

12.Popa V. Odjekivanje s. a. URL: http://www.prelepapoezija.com/odjekivanje/

\section{I. Yarmak,}

Doctor of Philology, Associate Professor,

Senior Researcher of the Slavic Languages Department

O. O. Potebnia Institute of Linguistics of NASU,

01001, Ukraine, Kyiv, 4, M. Hrushevsky St.,

tel.: (044) 279-02-92; inmo2006@ukr.net,

veronikaarmak1@gmail.com

\section{TRANSLATION TECHNIQUES IN BELARUSIAN INTERPRETATION OF THE SERBIAN LITERARY DISCOURSE}

\section{Summary}

Object: past tense verb forms in the Serbian and Belarusian literary languages. Subject: transformation varieties in Belarusian translation of the Serbian literary discourse, in particular for interpretation of different Serbian past tense verb forms in the mentioned East Slavic language.

Purpose: this research deals not only with defining of the most widely used translation techniques but also with revealing of functional peculiarities of past tense forms in the Serbian and Belarusian languages, in the context of historical dynamics of the contemporary outlines of their preterit system building. Methodology: linguistic observation and description, philological analysis, contrastive method, contextological analysis, as well as semantic and structural analysis.

Finding: the analysis of the Serbian and Belarusian linguistic material testified that a dominant place among numerous versions of translation techniques belongs to morphological substitution of Serbian past tense verb forms in Belarusian translation, that is caused by different historical development conditions of the Slavic languages belonging to various subdivisions. The universal past tense verb form in modern Belarusian subtly reflects shades not only of the Serbian Perfect with an auxiliary verb, but also those of truncated Perfect, synthetic Aorist and so forth. The author considers the most wide-spread difficulties in translation of "simple", traditional and kind of stylistically neutral Serbian verb forms, which are anyhow capable of concentrating deep senses. A notable place is taken by research of contextually possible Belarusian equivalents of the Serbian Perfect without an auxiliary verb, as well as of ways of interpreting the Serbian preterit verb forms that differ semantically in Belarusian.

Practical value: the research findings may be applied in teaching of special courses related to interSlavic literary translation, in compiling of two-language (Serbian-Belarusian and Belarusian-Serbian) dictionaries.

Key words: literary translation, transformations in translation, morphological substitution, Serbian preterit verb forms, Belarusian past tense verb forms. 